IRSH 59 (20I4), Special Issue, pp. I33-159 doi:I0.1017/So0208590I40003 I (C) 20I4 Internationaal Instituut voor Sociale Geschiedenis

\title{
Rickshaws and Filipinos: Transnational Meanings of Technology and Labor in American-Occupied Manila
}

\author{
MICHAEL D. PANTE \\ Department of History, Ateneo de Manila University \\ ${ }_{2}$ F Leong Hall, Katipunan Ave, Loyola Heights, Quezon City, \\ Philippines
}

E-mail: mpante@ateneo.edu

\begin{abstract}
This article tells the hitherto unknown history of the rickshaw in the Philippines. The Filipinos' encounter with this transport mode was brief and largely revolved around a failed rickshaw business in Manila in 1902. The venture quickly fizzled out, but not without controversy, deeply rooted in the colliding socio-political forces in the city at that time: the reliance on a non-motorized transport system; the consolidation of American colonial rule against the backdrop of an ongoing revolution; the birth of the first Filipino labor federation; and the implementation of a law banning the employment of Chinese workers from unskilled trades. The controversy turned the rickshaw into a disputed symbol. On the one hand, the rickshaw enterprise was criticized by Filipino carriage drivers and nationalist labor leaders, who viewed the vehicle as an essentially foreign apparatus that would enslave Filipinos. On the other hand, the Americans used the Filipinos' opposition to the rickshaw to prove the supposed un-modernity of the lazy native workers, who failed to grasp the idea of the dignity of labor. These disputes were inextricably linked to the clash of discourses between Filipino nationalism and colonial modernity, two competing perspectives both influenced by a comparative transnational frame.
\end{abstract}

What is presented in this article is the hitherto unknown history of the rickshaw in Manila. A history of the rickshaw still needs to be written for the whole region of Asia, ${ }^{1}$ and early twentieth-century Manila might

I. Peter Rimmer, "Hackney Carriage Syces and Rikisha Pullers in Singapore: A Colonial Registrar's Perspective on Public Transport, I 892-1923”, in idem and Lisa M. Allen (eds), The Underside of Malaysian History: Pullers, Prostitutes, Plantation Workers (Singapore, 1990), p. I60; David Arnold and Erich DeWald, "Everyday Technology in South and Southeast Asia: An Introduction", Modern Asian Studies, 46 (201 2), pp. I-17, 6. A regional history of the rickshaw has been attempted in an as yet unpublished paper by M. William Steele, "Mobility on the Move: The Rickshaw Conquers Asia". I would like to thank him for allowing me to read and cite his manuscript. 
just be the appropriate starting point for this huge undertaking. At first glance, selecting Manila as the springboard for a regional history of the rickshaw seems misplaced, if not outright ridiculous, given that there are other cities more deserving of this distinction. A substantial scholarly literature on the history of this vehicle exists, composed of historical accounts set in cities that have had a long relationship with the rickshaw. In contrast, the journey of the rickshaw in Manila was brief and undocumented. Apart from passing mentions in the works of William Henry Scott and Melinda Tria Kerkvliet, ${ }^{2}$ there is practically nothing in the academic literature that deals with it. Nonetheless, I argue that, though short, this particular encounter between city and vehicle was significant.

Historical literature on rickshaws has given the vehicle its rightful place in the historiography of colonial cities in Asia. These vehicles did not just form an integral part of the urban fabric of these cities, they also served as a useful analytical tool, as it were, to understand colonial rule. Moreover, a consequence of the increasing prominence of the rickshaw in literature was the centrality conferred upon the workers: the rickshaw-pullers. Once rendered mute in the historical record, pullers and coolies have been given due recognition in James Warren's Rickshaw Coolie: A People's History of Singapore, I880-1940. ${ }^{3}$ Warren has shown the value of analyzing the rickshaw in terms of the intersections of modern urbanity and labor relations in the age of Western imperialism in Asia, a mode of analysis that has been demonstrated in subsequent works by other scholars. $^{4}$

This article seeks to contribute to the growing literature on the history of rickshaws by focusing on the transnational understanding of the rickshaw. The transnational character of this vehicle was not just "physical" (manufactured using imported materials and then exported to different cities), but also in terms of the formation of imageries attached to the vehicle as absorbed and deployed by cosmopolitan travelers. The peak of rickshaw use in Asia corresponded to the period of late imperialism, an era characterized by a high degree of physical mobility within the region enjoyed even by certain elite groups among the colonized. The result was the traveling of meanings from one urban center to another. Moreover, the divergence

\footnotetext{
2. William Henry Scott, The Union Obrera Democratica: First Filipino Labor Union (Quezon City, 1992), p. 30; Melinda Tria Kerkvliet, Manila Workers' Unions, 1900-I950 (Quezon City, I992), p. I०.

3. James Francis Warren, Rickshaw Coolie: A People's History of Singapore, I880-1940 (Singapore, 2003).

4. Rimmer, "Hackney Carriage Syces"; Zwia Lipkin, Useless to the State: "Social Problems" and Social Engineering in Nationalist Nanjing, 1927-1937 (Cambridge, MA [etc.], 2006); Fung Chi Ming, Reluctant Heroes: Rickshaw Pullers in Hong Kong and Canton, I874-I954 (Hong Kong, 2005); Michael Tsin, Nation, Governance, and Modernity in China: Canton, 1900-1927 (Stanford, CA, 2002).
} 
of values attached to the act of rickshaw-pulling was often framed in comparative transnational terms. With the rickshaw seen as an essentially foreign vehicle in Manila, arguing for or against the dignity of labor in pulling a rickshaw necessitated comparisons with non-Philippine urban societies.

As such, I argue here that the brief encounter between Filipinos and rickshaws in the early twentieth century becomes significant only if understood in transnational terms. Contemporary newspaper articles, especially in the Manila Times, and travel accounts are the main primary sources due to the absence of archival materials that would have provided more details on this event. ${ }^{5}$ Using these sources, limited as they are, I show the convergence of social changes in Manila that intensified an otherwise fleeting encounter between man and machine. ${ }^{6}$

\section{THE RICKSHAW'S JOURNEY INTO THE PHILIPPINES}

The pre-World-War-II cities of Asia have a collective urban history with regard to their encounters with the rickshaw. This vehicle has had a long history of traveling from city to city in the region, beginning in the late nineteenth century. Interestingly, the rickshaw is often presented as a traditional vehicle, when to a large extent it is as cosmopolitan as the automobile in terms of both production and consumption. ${ }^{7}$ Its position as a ubiquitous vehicle in key Asian port cities during the heyday of Western imperial expansion turned it into a vehicle that gained overlapping meanings, a concept that will be discussed below.

The commonly accepted story regarding the origins of the rickshaw involves an American missionary in Japan who supposedly invented the vehicle in $1869 .{ }^{8}$ The vehicle was originally called jinrikisha, which literally means "human-powered vehicle", but usually contracted to rickisha while Western tourists usually pronounce it as "rickshaw". ${ }^{9}$ The rickshaw was an instant success; it was integrated into the transport systems of

5. I have consulted the most relevant administrative sources in this regard: Municipal Board of Manila, Report of the Municipal Board of the City of Manila for the period from August 7, I90I, to June 30, 1902 (Manila, I903); Municipal Board of Manila, Report of the Municipal board of the City of Manila for fiscal year ending June 30, 1903 (Manila, I904); however, these sources yield nothing about the rickshaw incident. The silence of the Municipal Board in these reports may mean that the authorities regarded the 1902 incident as insignificant or that they wanted to leave no trace of it in the public records.

6. The gender bias toward men in this statement is intentional. Men monopolized the labor force of Manila's urban transport system in the early twentieth century. On this, see Michael D. Pante, "A Collision of Masculinities: Men, Modernity, and Urban Transportation in AmericanColonial Manila”, Asian Studies Revierw, 38 (2014), pp. 253-273.

7. Steele, "Mobility on the Move".

8. Warren, Rickshaw Coolie, p. I4.

9. Mack Cretcher, A Tenderfoot in the Tropics (Topeka, KS, 1918), p. I8. 
Japan's main cities and it then spread across Asia in the last two decades of the nineteenth century. ${ }^{\mathrm{O}}$

Although rickshaws seem not to have been introduced in Manila in an enduring way, or in the Philippines for that matter, these vehicles did arrive in Manila and became a public mode of transportation, albeit for only a brief period. However, it must be noted that the Filipinos' first encounter with the rickshaw did not take place in the country; it happened when members of the middle-class intelligentsia, the so-called ilustrados, began their journeys abroad for further studies. These sojourns began in the r880s and continued in the next few decades. Although Europe was their main destination, almost all ilustrados stayed temporarily, but for a considerable length of time, in Asian cities, such as Hong Kong, Singapore, and Yokohama. ${ }^{\text {II }}$ It was in these cities that they first saw and rode in rickshaws. For example, Jose Rizal, the most well-known ilustrado and Filipino nationalist, mentioned in his letters his experience of seeing and riding rickshaws in Tokyo. ${ }^{\mathrm{I} 2}$

The actual date of the arrival of the first rickshaw on Philippine shores cannot be ascertained, but based on the primary sources I have consulted, the earliest mention of it is in the r89os. According to The Straits Times, an American company established a rickshaw company in Manila around August I 899. Based on a report in the Manila newspaper El Comercio, I,000 rickshaw units were imported for this purpose. ${ }^{13}$ Interestingly, the historian Kees van Dijk mentions that in the I890s an American businessman tried to introduce rickshaws into the country. Unfortunately, Van Dijk does not give the sources for this claim, so one cannot verify whether this is the same incident reported by The Straits Times. In any case, Van Dijk states that the I890s rickshaw experiment failed, leading him to conclude that rickshaws "did not become an accepted means of transportation" in the Philippines. ${ }^{14}$ Meanwhile, according to the Briton John Foreman, who visited the Philippines in I 899, the first person to use a rickshaw in Manila was a European consul who employed a Chinese puller. ${ }^{\text {Is }}$ There are also anecdotes about rickshaws pulled by Moros in Zamboanga City, which is located on the western tip of the southern

ı. Warren, Rickshaw Coolie, p. I4.

I I. Resil B. Mojares, Brains of the Nation: Pedro Paterno, T.H. Pardo de Tavera, Isabelo de los Reyes and the Production of Modern Knowledge (Quezon City, 2006). On the well-documented sojourns of ilustrados, see idem, Isabelo's Archive (Pasig City, 2013), pp. I43-I 54.

I2. Jose Rizal, Letter to Ferdinand Blumentritt, 4 March I888, in Jose Rizal, Epistolario Rizalino, Vol. V.r: Cartas de Rizal a Blumentritt en Alemán, I886-I888 (Manila, I938), p. 240. I3. "Jinrikishas at Manila", The Straits Times, I 8 August I899, p. 2.

14. Kees van Dijk, "Pedal Power in Southeast Asia", in Jan van der Putten and Mary Kilcline Cody (eds), Lost Times and Untold Tales from the Malay World (Singapore, 2009), pp. 268-282, 274 .

I 5. John Foreman, The Philippine Islands (Manila, I980), p. 635. 
island of Mindanao, in the early decades of the twentieth century. ${ }^{16}$ One observer even stated that Zamboanga was "the only place in the Philippines where jinrikishas have been introduced". ${ }^{17}$

Despite the existence of personal accounts by American colonial officials recalling the existence of rickshaws in Manila, ${ }^{18}$ what is clear is that these vehicles never became a popular public transport mode in the country. The apparent absence of the rickshaw in Manila was a point of contrast when early twentieth-century Westerners compared the city to its Asian counterparts. This was not lost on the Americans who began to occupy Manila in mid-I 898 . Many of them lamented the lack of a rickshaw system and saw it as an example of Manila's poor urban transport facilities. There were other transport modes in Manila at the turn of the nineteenth century, but these were perceived as inadequate by the new colonizers. ${ }^{19}$ During this period, the public urban transport system of the city was dominated by river-based vehicles, such as bancas and cascos, which were ridiculed and criticized by Manila Americans and other Westerners. Even land-based transport, such as the horse-drawn tranvia and the system of public carriages, did not escape these criticisms. ${ }^{20}$ Public carriages also came under scrutiny because of the Westerners' discomfort with the cocheros (carriage drivers). ${ }^{2 \mathrm{I}}$ There were even some Americans who said that the public transport system was so unreliable that owning a private carriage became a necessity. ${ }^{22}$ The frustration caused by the lack of a rickshaw system can be felt in Neil Macleod's reply to a question posed by General Arthur MacArthur regarding the use of rickshaws in the country: "No; they don't use them [rickshaws]. We are very far behind the times." ${ }^{23}$

16. William Boyce, The Philippine Islands (Chicago, IL, I9 I4), p. I76; Charles Thomson, Terry: A Tale of the Hill People (New York, 1921), p. 35.

17. "The Port of Zamboanga", The Mindanao Herald: Historical and Industrial Number, 3 February 1909, p. 64.

18. Charles Burke Elliott, The Philippines to the End of the Commission Government: A Study in Tropical Democracy (New York, I968 [1917]), p. 279.

19. Michael D. Pante, "Ang sasakyan at lansangan bilang paaralan: Modernisasyon ng transportasyong panlungsod at lipunan sa Manila, I900-194I”, Malay: Internasyonal na Journal sa Filipino, 23 (201 I), pp. II I-I26, I I3; idem, "The Cocheros of American-Occupied Manila: Representations and Persistence", Philippine Studies: Historical and Ethnographic Viewpoints, 60 (2012), pp. 429-462, 435 .

20. US Bureau of Insular Affairs, Monthly Summary of Commerce of the Philippine Islands, July, 1902 (Washington DC, c.1903), pp. I2-I3; Victor Clark, "Labor Conditions in the Philippines", Bulletin of the Burean of Labor, 58 (1905), p. 830; Campbell Dauncey, An Englishwoman in the Philippines (London, 1906), pp. 92-93.

21. Pante, "The Cocheros of American-Occupied Manila".

22. Arthur Brown, The New Era in the Philippines (Nashville, TN, 1904), pp. 93-94; Ronaldo B. Mactal, Ang pang-araw-araw na bubay sa Maynila sa panabon ng Digmaang Pilipino-Amerikano, I898-190I (Manila, 2010), p. Is8.

23. US Philippine Commission, Report of the Philippine Commission to the President, Vol. II:

(Testimony and Exhibits) (Washington DC, 1900), p. 39. 


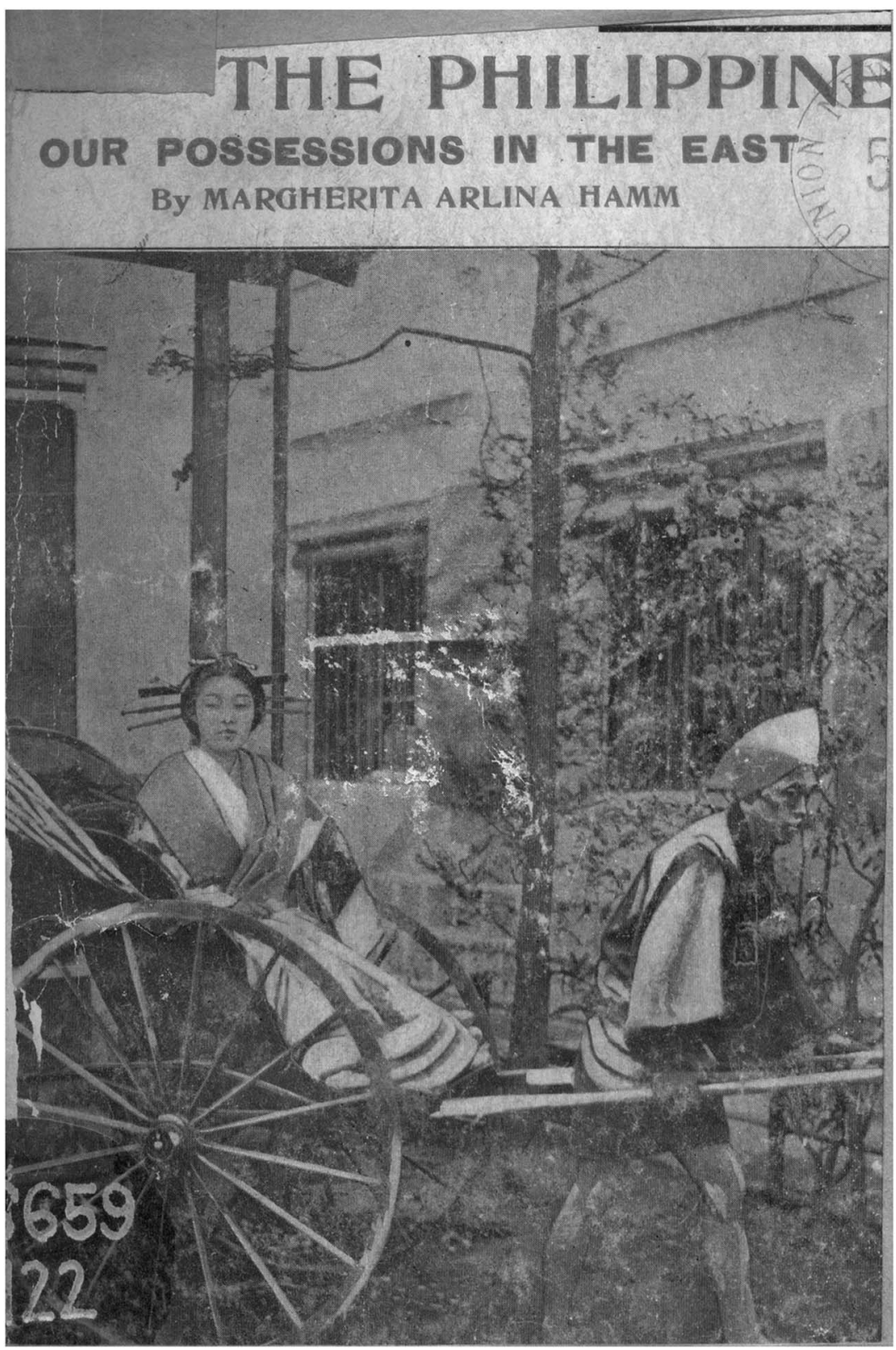

Figure I. Cover photograph of a travel account written by an American journalist to describe her trip to the Philippines. It shows a rickshaw with a puller and a passenger, although the author did not identify the actual location where this photograph was taken.

From: Margherita Arlina Hamm, Manila and the Philippines: Our Possessions in the East (London, I898). 
Such a widespread perception of Manila's urban transport system is a crucial element in understanding American-colonial Manila at the start of the twentieth century. Manila was a highly urbanized and cosmopolitan city, a site for businesses engaged in international trade. The wage-labor system in the city was in the process of replacing old methods of labor mobilization, such as the employment of Chinese coolies (predominant in Manila when the American colonizers first arrived, but already waning by 1902 and about to be rendered illegal by impending legislation, the Chinese Exclusion Act). Commercial activities relied then on Chinese labor gangs, which were secured for businesses by patrons, who handled all payments. ${ }^{24}$ While numerous Chinese coolies were still employed in various enterprises in the city, ilustrados were organizing the nascent Filipino proletariat into a nationalist working class. ${ }^{25}$ This last point was connected to the atmosphere of revolt and frustrated independence cut short by American intervention in the Philippine anti-colonial revolution against Spain. The intersections of these factors and events provide the backdrop for Manila's brief and yet significant encounter with the rickshaw in 1902 .

\section{THE 1902 RICKSHAW CONTROVERSY}

On 8 January 1902 the Municipal Board of Manila, the capital's Americandominated local government, received from American entrepreneur Carlos S. Rivers an application to import several hundred rickshaws. ${ }^{26}$ The application was then referred to a committee of the Municipal Board. In response the Board requested a meeting with Rivers and the Chief of the Metropolitan Police to discuss the matter.

The American community in Manila welcomed the news. An editorial in the Manila Times, the so-called voice of the American expatriate community, expressed optimism about the proposal and believed that the plan would be "hailed with rejoicing by the public". ${ }^{27}$ The newspaper had long argued in favor of this transport mode, given its editors' frustration with the existing urban transport system. The editors even presented the rickshaw in the same light as the automobile as far as the improvement of passenger mobility was concerned: "With automobiles and rickshas the public should at last be afforded relief from the tyranny of the cochero and the general inadequacy of the present system of street conveyances." 28

24. Greg Bankoff, "Wants, Wages, and Workers: Laboring in the American Philippines, I 899-1908”, The Pacific Historical Review, 74 (2005), pp. 59-86, 80.

25. Kerkvliet, Manila Workers' Unions; Scott, The Union Obrera Democratica.

26. "Manila May Have Rickshas", Manila Times, 9 January ı 902, p. I; "Mr. Carlos S. Rivers", El Comercio, 27 January 1902, p. 5.

27. "Editorial", Manila Times, 9 January 1902, p. 4.

28. Ibid. 
According to the Manila Times, Governor-General William Howard Taft himself had advocated the use of rickshaws in Manila even before Rivers's application, but believed that previous conditions in the city would have turned the rickshaw into a controversial issue because "it was then considered by the military authorities [...] that conditions were not sufficiently settled for such an innovation [...]. Now conditions are different, and the only difficulty in the way of the proposition would appear to be in the motive power." 29 Taft's statement was revealing on two counts. First, he resorted to a euphemism (i.e. his use of the term "motive power") to avoid referring to the rickshaw as a transport mode that was propelled by human beings. And secondly, which would also help explain the first point, he supposed a rickshaw system in Manila could have been politically contentious under certain circumstances. His views were not unfounded, as succeeding events would reveal.

By late January the Board had given Rivers the signal to go ahead, but not without some criticism from the American press, which felt that Board President Arsenio Cruz Herrera was too slow in implementing "American urban methods", i.e. approving the rickshaw proposal. ${ }^{30}$ The Board issued Rivers's Luzon Jinricksha Company with a permit to import a few hundred rickshaw units and place them in service. ${ }^{3 \mathrm{I}}$ The business also obtained financial security when the American Bank agreed to issue shares to potential investors in the company. ${ }^{32}$ However, just a few days after these events, rumors spread that certain groups opposed the rickshaw scheme. The Manila Times disputed the rumors and reported that, on the contrary, no-one opposed Rivers's plans. The Manila Times report, however, was an obvious attempt to protect a business venture that it supported.

On 7 February the Manila Times reported Rivers's promise to bring in I,000 coolies to serve as pullers. The pullers would be divided into two shifts of 500 pullers each (one shift to be dispatched from 6 am to $3 \mathrm{pm}$, the other from $3 \mathrm{pm}$ to $\mathrm{I} 2 \mathrm{am}) .{ }^{33} \mathrm{~A}$ few days after, Rivers petitioned the Municipal Board to allow him to import a further 500 rickshaws - despite the fact that the first consignment had yet to arrive - believing that the business would be a "paying investment". ${ }^{34}$ Such a move could be interpreted as unfounded optimism, but if one looks at Rivers's actions in

\footnotetext{
29. "Manila May Have Rickshas", p. I.

30. "Pres. Herrera's Stand", Manila Times, 23 January 1902, p. 4.

31. "Manila Will Have Rickshas", Manila Times, 3 I January i902, p. I. Rivers's franchise was not exclusive however. Other private entities interested in putting up their own public rickshaw system were allowed to apply for a permit, although primary sources revealed no other individual or company that signified their intention to do so. See "The Ricksha Scheme", Manila Times, 7 February 1902, p. 8.

32. "The Luzon Ricksha Company", Manila Times, 5 February i902, p. I.

33. "The Ricksha Scheme", p. 8.

34. "Wants Five Hundred More Rickshas", Manila Times, I 2 February I902, p. I.
} 
other aspects of his business he was actually preparing for considerable trouble related to issues of labor. Apparently the company already had qualms regarding the feasibility of employing Chinese coolies as pullers, despite their prominence and reputation in Manila at that time as reliable workers. In this regard the company wrote to the Collector of Customs to ask for permission to import Japanese coolies for the said purpose. A glimmer of hope presented itself to Rivers when he was able to have a talk with the Japanese consul in Manila, who was initially reported to have stated that Japanese coolies would be banned from leaving Japan. The consul, however, made it clear to Rivers that Japanese coolies could be obtained for the rickshaw plan. The discussion with the consul was a positive development for Rivers, who had also made arrangements with a company in Yokohama for the importation of coolies. Rivers explained that he preferred Japanese rickshaw-pullers because they were "much more attentive and considerate than the Chinese and not so likely to be insolent". ${ }^{35}$

Meanwhile, Edith Moses, wife of Philippine Commission member Bernard Moses, recognized that the rickshaw plan was facing considerable opposition to the point that the feasibility of importing coolies had been put into question. In her memoirs dated i I February 1902 she wrote:

There has been an effort made here lately to start a riksha company, and we thought it would succeed, but the Chinese and Japanese consuls and citizens have protested against "making beasts of human beings", and the company cannot get coolies to pull the rikshas. The rikshas are, I hear, still in the customs house. The English consul uses one, and his coolies seem quite as human as some of the dirty barelegged drivers who beat broken-down ponies about the streets. ${ }^{36}$

The complexity of the issue of the importation of coolies was initially a legal matter. In a 2I March 1902 in a letter sent by Collector of Customs W. Morgan Shuster in response to a previous letter from the Luzon Jinrikisha Company, which inquired about the legality of importing Japanese coolies, he cited Section 5 of the 1885 US law entitled "An act to prohibit the importation and migration of foreigners and aliens under contract or agreement to perform labor in the United States, its Territories, and the District of Columbia". The restrictions of this law only covered unskilled laborers. He cited this law to conclude that Japanese coolies could not be categorized as skilled workers and that the necessary labor for the rickshaw service could be obtained in the country, given the presence of Chinese coolies. ${ }^{37}$ With such legal barriers, the

35. "The Delay in the Rickshas", Manila Times, i8 May 1902, pp. I, 8.

36. Edith Moses, Unofficial Letters of an Official's Wife (New York, 1908), p. 2 I 3.

37. W. Morgan Shuster, "Importation of Japanese Jinrikisha Coolies Prohibited", in Philippine Customs Service, Chinese and Immigration Circulars (Annotated): Vol. I, Nos. I to 197, December, I90I, to December, I907: Constructions and Decisions (Manila, I908), pp. 35-36. 
company lost its case, notwithstanding the fact that it was not the only establishment that wanted to secure Japanese coolie labor. ${ }^{38}$

At this point it was quite apparent that, while the company desperately tried to avoid hiring Chinese coolies, at the same time the idea of employing Filipino laborers was clearly out of the question. But why? The answer lies in the tumultuous and politically charged labor situation in Manila during the early years of the twentieth century. Despite the initial optimism of the Manila American community, opposition to the rickshaw plan intensified in the first half of I902. And opposition came on two different fronts: Filipino labor groups and Chinese coolies. With Shuster's decision, the rickshaw company was now caught between a rock and a hard place.

Rivers was certainly aware of opposition from Filipino laborers, especially the cocheros. On I 8 May the Manila Times reported that, although the first installment of imported rickshaw units (twelve vehicles) had arrived from Japan on 13 May, the inauguration of the rickshaw business would be delayed due to the "unfortunate jumble in packing pieces in Japan" ${ }^{39}$ These units were assembled in Tokyo and were made to "run down on their own running gear", i.e. rolled as complete rickshaws to Yokohama, where they were disassembled again for shipping. However, the most interesting detail in the article was that, when the shipment arrived, Rivers assembled one rickshaw and rode on it "merely as an experiment, to see if any malicious cochero would run him down or if any bellicose hombre would hurl a brick at him". ${ }^{\circ}$ No-one did so; instead, the rickshaw got the attention of Manila City Hall employees. Nonetheless, Rivers's pronouncements revealed his hidden anxiety toward the cocheros' possible hostile reception to his business. In another Manila Times article, a cochero was asked for his opinion about rickshaws. The cochero replied that he did not believe rickshaw-pullers could run at the pace Americans wanted. ${ }^{4 \mathrm{I}}$

The cocheros' opposition to the rickshaw plan was made more potent by their decision to organize themselves. In 1902 a cochero section was established within the Union Obrera Democratica (UOD), the first Philippine labor federation, which was composed mainly of Manila-based unions of lithographers, printers, and bookbinders, and led by wellknown nationalists Isabelo de los Reyes and Hermenegildo Cruz. ${ }^{42}$ With this development, the anti-rickshaw campaign intensified to the point that it caused the delay of rickshaw operations. ${ }^{43}$ On I9 May the UOD

38. Edgar G. Bellairs, As It Is in the Philippines (New York, I902), p. I 58.

39. "The Delay in the Rickshas", p. I.

40. Ibid., p. 8.

4I. "The Rickshas", Manila Times, 22 May 1902, p. 4.

42. Scott, The Union Obrera Democratica, pp. 32-33.

43. "Editorial", Manila Times, 25 May 1902, p. 4. 
released a statement entitled "Los Filipinos no son brutos" 44 [Filipinos are not beasts] as a protest against the planned rickshaw business. The UOD opposed Rivers's plans because they believed that if Filipinos were hired as pullers they would become the slaves of foreigners. Cruz asked his fellow Filipinos not to allow themselves to be employed as pullers, lest they become traitors and submit themselves to this "unholy", "despised and devil-contrived vehicle". ${ }^{45} \mathrm{He}$ coaxed cocheros to launch a "cochero insurrection" against the rickshaws, which would have been an alternative transport mode to the carriages the cocheros drove. Reacting to the decision of the Municipal Board to grant Rivers a permit, Cruz stated that "God will never forgive him [Herrera] for allowing such satanic monstrosities". Apparently Cruz knew that a number of Filipinos had already committed to serve as pullers, leading him to urge other Filipinos not to use rickshaws if these were pulled by "our brothers". He added that he could not blame Filipino pullers, "whose ignorance and weakness [were] being exploited by certain people". ${ }^{46}$

Rivers's response to Cruz's polemics marked a key point in the debate. Rivers declared that he would not hire Filipinos as pullers because he believed that they were lazy and ineffective workers. ${ }^{47}$ Rivers found allies in the editors of the Manila Times, who opined in an editorial comment that the "transportation problem" in Manila could not be solved without a rickshaw system, given that cocheros were unreliable. ${ }^{48}$ Such an inadequacy in labor, from the editors' perspective, was the root of the problem and was even compounded by the recent enactment of the Chinese Exclusion Act. ${ }^{49}$ The new law prohibited the employment of Chinese coolies in non-skilled trades. Though Rivers preferred Japanese over Chinese coolies, the legislation was still a big blow to the rickshaw plan and its proponents, for it left them no option but to depend on supposedly unreliable Filipino laborers, who were also being mobilized by Filipino labor organizers to boycott the rickshaw.

Despite the politically charged atmosphere, the Luzon Jinrikisha Company began operations on 24 May at $2 \mathrm{pm}$. On its first day, out of a total of 300 rickshaw units stored at godowns built inside Puerta Isabel Segundo (located within the walls of Intramuros, the oldest part of the city center of Manila), 20 plied the city streets. In violation of the Chinese Exclusion Act, Rivers decided to employ Chinese coolies as pullers, many

44. "Los Filipinos no son brutos", El Comercio, i9 May 1902, p. 3.

45. "Appeals to His People”, Manila Times, 23 May 1902, p. I.

46. Ibid.

47. "Rickshas Are Running", Manila Times, 25 May 1902, p. I.

48. "The Labor Problem", Manila Times, 23 May I902, p. 4.

49. Clark Alejandrino, A History of the 1902 Chinese Exclusion Act: American Colonial Transmission and Deterioration of Filipino-Chinese Relations (Manila, 2003). 
of them reportedly former stevedores and unemployed coal-handlers, ${ }^{50}$ and a few Filipinos, who became "objects of ridicule". 5 I The total number of 300 rickshaw units was a drastic decrease from the proposed 500, which would be deployed in I 2 stations: Plaza Moraga (I00); Pasaje de Perez near Escolta (I00); Plaza de Santa Cruz y Goiti (50); Customs House (20); Captain of the Port (20); Plaza de Binondo-Oriente Hotel (40); Malate (20); Ermita (30); Walled City (Intramuros)-Puerta Parian (30); Malacanang Palace (20); City Hall (20); Bridge of Spain, south side (50). ${ }^{52}$

Based on the locations of the rickshaw stations, American customers were clearly the main clientele because the majority of the stations were at centers of government, businesses, and residences of Americans. Their continued strong support for the business was thus not surprising. In its editorial, the Manila Times recognized the Filipinos' right to protest against Rivers's venture but qualified it by stating that "they had better not make any demonstration when Americans are riding in the rickshaws or their crusade will be both short-lived and fraught with sorrow".53 The editorial was harsh and hostile, a reflection of how serious the rickshaw controversy was for the Manila Americans. It also blamed certain Filipinos for scaring off pullers and for the delay in rickshaw operations, and even posited that this issue would set the Manila Times against Filipinos. The editors argued that they could not allow Manila's poor public transport system to continue, which was supposedly forcing American women who did not own private rigs, especially those who traveled from home to Escolta and back, to go on foot just to travel within the city. ${ }^{54}$

Notwithstanding the assertive stance of the American press in its support, the rickshaw business found itself already crumbling within the next few days. On its second day, no puller reported for work, and the following day, only one did so. However, this time around, the cause behind the breakdown in operations was opposition not from Filipinos but from the Chinese. The sudden absence of Chinese coolies was supposedly due to pressure from the Manila Chinese community, which felt humiliated by their compatriots who chose to be pullers. Placards were seen posted around the city that served as a "friendly warning" to coolies

50. Edgar Bellairs, Correspondent in Manila from the Associated Press, mentioned that the company began with three Chinese as pullers. Though it was clear that he witnessed the unfolding of the rickshaw controversy in Manila, Bellairs failed to provide a detailed recollection, leading me to put more trust in Manila Times articles regarding facts surrounding this event; Bellairs, As It Is in the Philippines, p. I59.

5. "Rickshas are Running", p. I; Scott, Union Obrera Democratica, p. 30; Foreman, The Philippine Islands, p. 635 .

52. "Ricksha Stands", Manila Times, 2 February 1902, p. I.

53. "Editorial", Manila Times, 25 May 1902, p. 4.

54. Ibid. 


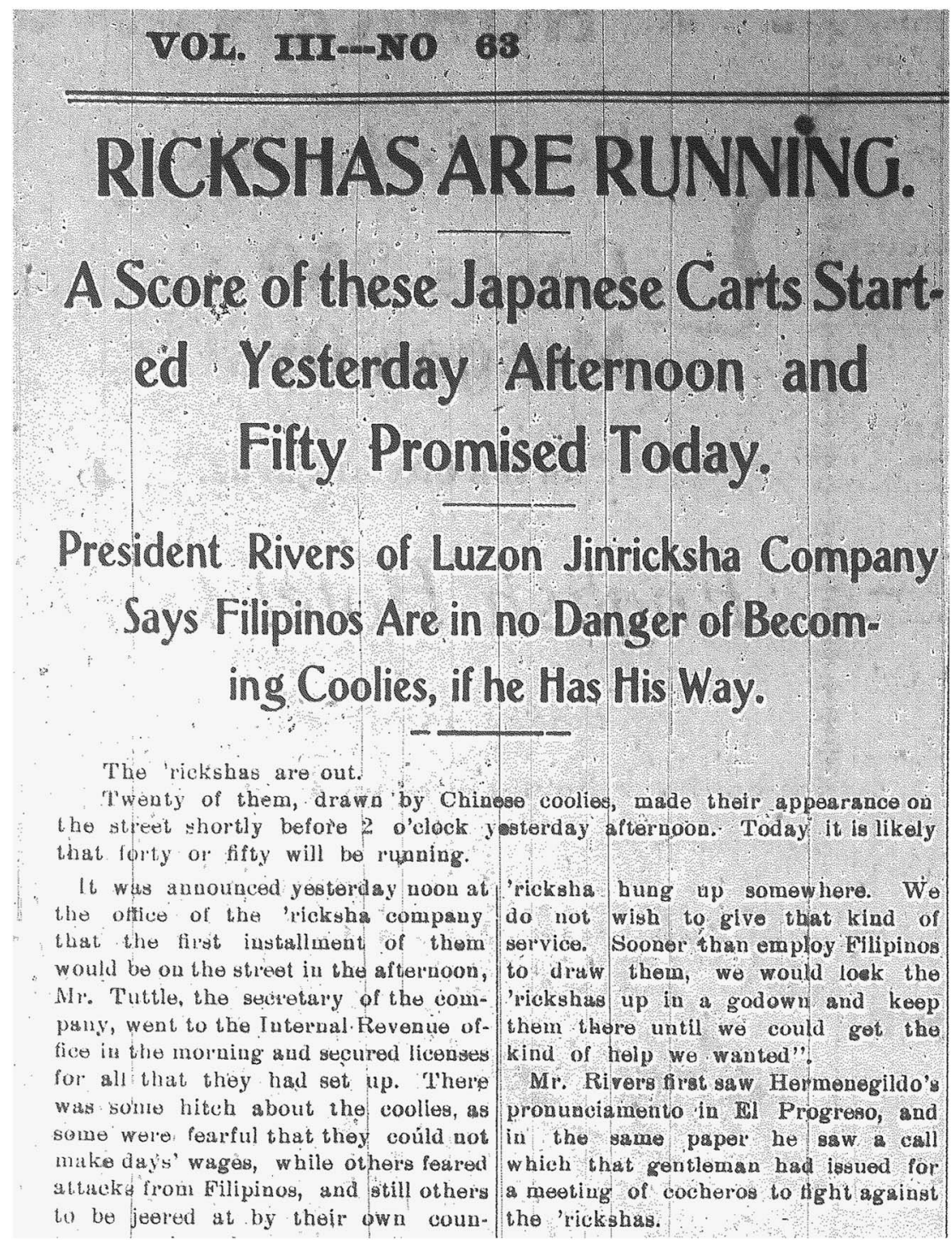

Figure 2. The Manila Times headline announcing the start of operations of Carlos Rivers's rickshaw company.

From: "Rickshas are running", Manila Times, 25 May 1902, p. I. Photograph courtesy of Microform Reading Center, Rizal Library, Ateneo de Manila University.

not to be draught animals for foreigners. Asked to comment, Rivers, who had brought the matter to the police, entertained the idea that Filipino oppositionists put up the placards. The "warnings" also affected the Chinese coolie contractor, who was visited by certain Chinese who 
threatened him. ${ }^{55}$ Meanwhile, according to Foreman, the Chinese consulate prohibited the employment of Chinese coolies as pullers. ${ }^{56}$ Scott corroborates this point by stating that the Chinese consul himself posted placards, "in elegant calligraphy hinting that any Chinese who touched the shafts of a rickshaw would be deported [to Hong Kong] with his queue cut off".57 The consulate's actions as narrated by Foreman and analyzed by Scott seem to contradict the reports of the American press, which mentioned that the Chinese consul talked to and sympathized with Rivers expressing disappointment over recent events. According to the reports, after the two talked Rivers concluded that the placards were the work of the Chinese and not Filipinos. ${ }^{58}$

Pressure on the rickshaw company mounted in succeeding days. On May 27 the UOD petitioned for the banning of rickshaws and the strict implementation of the Chinese Exclusion Act. ${ }^{59}$ Although six rickshaws plied the streets on the day that the UOD released its petition, Rivers now believed that it was already useless to rely on the Chinese pullers. $\mathrm{He}$ believed that behind all these covert acts to disrupt rickshaw operations was a "syndicate", which exerted undue influence over Chinese coolies. He was already desperate at this point, leading him to consider calling Acting Governor-General Luke E. Wright and asking for action from no less than the Philippine Commission, especially with regard to his plea to allow the importation of Japanese coolies. ${ }^{60}$

Reaffirming its support for the rickshaw business, the American press launched a tirade against the UOD and its supporters. This time the anger was vented mainly against cocheros. The Manila Times lambasted the cocheros for failing to understand the "dignity of labor" that had ultimately kept Manila's urban transport system backward. ${ }^{61}$ But just like Rivers, the Manila Times also appeared to have abandoned the idea of pursuing Chinese coolies. On 28 and 29 May the Manila Times released consecutive editorials that put forward the idea of importing Japanese coolies to serve as pullers. ${ }^{62}$ Knowing that critics would invoke the Exclusion Law against this proposal, the editors defended their stance by

55. "A Ricksha Strike", Manila Times, 27 May 1902, pp. I, 8. One must take note that while the Manila Times referred to the pullers' actions as a "strike", technically speaking, these acts of resistance cannot be labelled as such. Perhaps the editors did so in order to cast these pullers in a negative light.

56. Foreman, The Philippine Islands, p. 635.

57. Scott, Union Obrera Democratica, p. 30.

58. "A Ricksha Strike", pp. I, 8.

59. "Wants Higher Wages", Manila Times, 28 May i902, p. I.

60. Ibid.

6r. "Filipinos and Rickshas", Manila Times, 28 May 1902, p. 4.

62. Ibid.; "Ricksha Labor", Manila Times, 29 May 1902, p. 4. 
stating that rickshaw-pulling should be classified under skilled labor in contrast to the assessment of immigration officials.

On 4 June the Luzon Jinricksha Company held a meeting in its office at Calle San Juan de Letran in Manila. ${ }^{63}$ The company sent a petition to the Philippine Commission the following day asking for permission to import Japanese coolies as pullers. ${ }^{64}$ However, the reports of the Manila Times on the rickshaw business end here. The controversy did not appear in the pages of the newspaper any more in the succeeding months. The silence could only mean one thing: Rivers's plans had fizzled out and died a natural death. In his assessment, Edgar Bellairs, Manila Correspondent of the Associated Press from I901 to I902, looked at the issue from the perspective of the Chinese pullers' practical decision-making: "The majority of the Chinese left were making far too much in other directions for them to take to the hard manual labor of rickshaw-pulling. On the other hand, the Filipinos were not only unable, but unwilling." In the end he lamented the demise of a supposed grand plan for Manila's development: "the rickshaws are lying in Manila useless, badly as they are needed in the streets for transportation". ${ }^{5}$

\section{THE DIGNITY OF LABOR}

In the aftermath of the controversy it was apparent that the proponents of the rickshaw system had failed in their objective. It is difficult to identify a single factor that led to this failure, but one could assert that the business was not so viable to begin with. First, it was driven by demand from Manila Americans, who comprised a small fraction of the city population. Another factor was its fare rate, which was io cents for every is minutes. In contrast, carromatas, also referred to as the commoners' carriages, charged less than io cents for a half-hour ride. ${ }^{66}$ Of course, labor politics also worked against Rivers's business, as discussed in the previous section.

Consequently, the vehicles were taken out of the country. ${ }^{67}$ By 1904 Arthur Brown had reported that rickshaws were unknown in Manila. ${ }^{68}$ In its assessment of the events, the Bureau of Insular Affairs presented its prediction for Manila's transportation system: "[b]ut with the climatic conditions and distances in Manila against it, it is not believed that it will afford any relief to the present congested transportation facilities". ${ }^{69}$ Even

63. "Meeting of the Jinricksha Co.", Manila Times, 4 June 1902, p. I.

64. "The Ricksha Coolie Trouble", Manila Times, 6 June 1902, p. I.

65. Bellairs, As It Is in the Philippines, p. I59.

66. "Rickshas will Run Today", Manila Times, I6 May I902, p. 8; Pante, "The Cocheros of American-Occupied Manila", p. 432.

67. Foreman, The Philippine Islands, p. 635.

68. Brown, The New Era in the Philippines, p. 94.

69. US Bureau of Insular Affairs, Monthly Summary of Commerce, p. I3. 
the Singapore press took note of the 1902 rickshaw affair. The Straits Times, in an untitled commentary, mentioned that the "strong prejudice against the Chinese there mar[red] the success of the enterprise". It also added: "The Filipinos are too lazy to work at pulling and Filipino drivers molest the pullers. Swell Chinese at Manila fancy that rikisha pulling is degrading to their race." 70 The Englishwoman Campbell Dauncey offered additional insights worth quoting at length:

One thinks regretfully of the delightful luxury of the rickshaws and chairs of the real Far East, and I was very much surprised to see none of these luxurious comforts when we first arrived in the Philippines. It seems that a company was formed some years ago to introduce them, and got the concession to bring rickshaws and coolies from China, but as soon as these useful institutions appeared in the streets of Manila, the Filipinos stoned them, and at last forced the American authorities to banish the innovation altogether: "For", said the astute and progressive Filipino, "the next thing will be that we shall be made to draw these things about, and we will not be treated as animals."

Fancy giving in to them! And fancy thinking of a splendid country and people like Japan, "where the rickshaws come from", and listening to such preposterous nonsense from a Filipino! But these ignorant half-breeds got their way, and the only example they had ever had of energy or of the real dignity of labor was promptly withdrawn to please them. ${ }^{71}$

Clearly, the rickshaw controversy went beyond the issue of physical mobility as hinted in the commentaries of Dauncey and The Straits Times. The controversy, albeit brief, turned the rickshaw into a disputed symbol, which saw the overlapping of the issues of race, labor, colonialism, and modernity, a product of layer upon layer of various encounters with the rickshaw experienced by the different actors involved in the controversy. The issue of the dignity of labor was illustrative of the disputed nature of the rickshaw as a symbol because it could be viewed from various competing perspectives, as will be explained in the succeeding paragraphs.

To understand the gravity of the situation from the Americans' perspective, one has to take note of their frustrations with the city, beginning with the then prevailing transport system in Manila. Adding to their disappointment was what they believed was a "backward" system of procuring labor. They were surprised to find out that a free labor market was almost non-existent in the country - even in the capital city of Manila $\mathrm{a}^{72}$ - including the land transportation sector. ${ }^{73}$ When it became apparent that most Filipino workers would not agree to be employed as

70. [Untitled], The Straits Times, i 8 June 1902, p. 4.

71. Dauncey, An Englishwoman in the Philippines, p. 93.

72. Bankoff, "Wants, Wages, and Workers", p. 66.

73. Clark, "Labor Conditions in the Philippines", p. 830. 
pullers, the American press took this as evidence of their lack of understanding of the dignity of labor. Taken together with Rivers's depiction of Filipino workers as lazy, the American press chastised the Filipinos for treating pulling as a lowly and degrading occupation.

While Westerners were hesitant to rely on Filipino labor, their demand for Chinese coolie labor was high, especially in Manila. ${ }^{74}$ Although a diversity of opinion existed among Western businessmen regarding this matter, their strong opposition to the Chinese Exclusion Act revealed the predominant sentiment. ${ }^{75}$ The newspaper articles that reported on the rickshaw controversy of 1902 did not give a detailed profile of the pullers. However, based on the context of early twentieth-century Manila, the pullers employed in Rivers's short-lived business most probably came from the ranks of Chinese coolies who had been employed in elite households since the late nineteenth century and who also made up the labor pool for Singapore's rickshaws. ${ }^{76}$ Indeed, the rickshaw controversy demonstrated the prevailing attitude among them. The American press even propounded the idea that rickshaw-pullers were skilled laborers and that, therefore, the Exclusion Law was not applicable in this case. The bias of Western business owners against Filipino workers and their preference for Chinese coolie labor heightened the Americans' frustrations with this new law even more. ${ }^{77}$

In contrast, many Filipinos understood their resistance to the rickshaw business as an assertion of laborers' dignity. A significant point here was that such a stance was articulated mainly by organized labor, namely the UOD, an act that proved critical in the eventual demise of Rivers's business. The significance of the UOD's opposition was its timing: the rickshaw controversy erupted just a few months after the founding of the UOD on 2 February 1902, an event that marked the establishment of the first labor federation in the Philippines. ${ }^{78}$ In fact, the controversy happened when the UOD was in the middle of a major labor strike that the federation spearheaded, and in one of the strikers' meetings, orations and speeches that dealt with the ongoing issue were delivered. ${ }^{79}$ The rickshaw controversy presented UOD ideologues, particularly de los Reyes and Cruz, with an opportunity to consolidate its ranks and articulate its vision as an organization that fought for Filipino workers.

74. Ibid., p. 86r; Julia Martínez and Claire Lowrie, “Transcolonial Influences on Everyday American Imperialism: The Politics of Chinese Domestic Servants in the Philippines", Pacific Historical Review, 8I (2012), pp. 51 I-536.

75. Alejandrino, A History of the 1902 Chinese Exclusion Act, pp. 18-20.

76. Edgar Wickberg, The Chinese in Philippine Life, I850-I898 (Quezon City, 2000); Martínez and Lowrie, "Transcolonial Influences"; Warren, Rickshaw Coolie.

77. Bankoff, "Wants, Wages, and Workers", p. 71.

78. Scott, The Union Obrera Democratica, pp. $21,30$.

79. "The Strikers Meet", Manila Times, 7 June 1902, p. I. 
Although de los Reyes had already become notorious within the Manila business community because of the workers' strikes he had led at that time, ${ }^{8 \circ}$ the controversy still served as a litmus test for the nationalist UOD, and even the American press recognized the symbolic value of the issue for Filipino nationalism. A Manila Times editorial stated: "The most regrettable feature of the opposition of the Filipinos to the jinricksha movement will be the idea of their own omnipotence which will seize them if they succeed in rendering it a failure." ${ }^{81}$ To convince fellow Filipinos of the inhumanity of rickshaw-pulling, Cruz and de los Reyes deployed, borrowing Michael Salman's words, "metaphorics of slavery". ${ }^{82}$

Nevertheless, a number of Americans respected, supported, and praised the Filipinos' resistance to the rickshaw project. W.C. West, in his analysis of the Philippine transportation system, stated that: "Manila and the Philippines certainly have cause to congratulate themselves that every attempt to introduce the jinrikisha or any description of man-propelled vehicle has failed." ${ }^{83}$ American surgeon Robert Hart shared West's opinion but with a deeper level of introspection:

Incidentally, the stranger having previously visited Japan, China, India or the Straits Settlements, will be surprised at not finding the rickshaw in use in the Philippines. They were introduced at one time in Manila but no one, no matter how humble, could be found among the Filipino to draw them, as the native is possessed of a very considerable amount of natural dignity and the substitution of a man for a pony aroused such a storm of indignation that the company who had endeavored to introduce these vehicles were glad to ship them out of the islands. ${ }^{84}$

Hart's views were an articulation of a fairly common tendency among Westerners to perceive the rickshaw as a vehicle that was essentially oppressive to the puller. Also, among Americans in the US and in Manila, there were those who felt that having a rickshaw system was incompatible with the purported modernizing thrust of American colonialism. David Doherty, a doctor from Chicago and an ardent anti-imperialist, ${ }^{85}$ who visited the Philippines for several months, went even further by suggesting that the Filipinos were Western in perspective based on their response to the

80. Bellairs, As It Is in the Philippines, p. I60.

8. "Editorial", Manila Times, 30 June 1902, p. 4.

82. Michael Salman, The Embarrassment of Slavery: Controversies over Bondage and Nationalism in the American Colonial Philippines (Quezon City, 200I), p. I 23.

83. W.C. West, "Highway Transportation in the Philippines", The Philippine Review, I (November 1918), p. 75 .

84. Robert Hart, The Philippines Today (New York, I928), p. Iо.

85. Lewis E. Gleeck, Jr, The American Half-Century (I898-1946), rev. edn (Quezon City, I998), p. 72. 
rickshaw system. In his paper presented to the US Senate he concluded, albeit in racist fashion:

[...] the Filipino, after three centuries of Christian and Spanish influence, and after a considerable race intermixture with Spaniard and Chinese, is no longer a Malay. He really is the outpost of western civilization on the shores of the Orient. His ideals and aspirations are European; his views on the questions of Japanese rickshaws (the attempt to introduce which into Manila was defeated by a storm of popular indignation); of opium toleration (to which he is opposed); of Chinese labor, are certainly western. ${ }^{86}$

Interestingly, Doherty was also vocal in his opposition to the importation of Chinese labor and a believer in the capacity of Filipinos as efficient laborers. ${ }^{87}$

In Manila a number of Americans expressed their concern that the rickshaw system was inconsistent with the supposed values the US was to uphold as a colonizer. The Manila Times even had to defend its prorickshaw position vis-à-vis Manila Americans who were against it. In a letter to the editors of Manila Times, a "constant reader" commented that the Manila Times was not being faithful in representing the spirit of the US in the Philippines when it advocated the use of rickshaws. The letter also noted that the cocheros could not be blamed, given that demand for transportation in the city exceeded supply. "Constant reader" then shared his/her analysis:

Let us not retrograde. Of course it is easy to perceive whence the cry for "rickshas" comes. It comes from our British brethren. The "rickshaw" is fast enough for Singapore and Shanghai; but if Manila is to become an American city, the man in the "rickshaw" will be getting there while the man in the "mobile" has gotten there [...]. But let us be modern, let us encourage "mobile" companies, railway companies. Let us move forward, not backward. ${ }^{88}$

Based on this letter to the editor, a certain transnational frame informed the negative view of the rickshaw, a frame shaped by the transnational mobility of Westerners within various Asian cities. This transnational frame provided anti-rickshaw commentators with a comparative vista that lent legitimacy to their remarks, as demonstrated in Hart's identification of a hypothetical (obviously Western) stranger visiting Japan, China, India, and the Straits Settlements. However, the legitimacy of transnational experience also applied to those who advocated the use of rickshaws, as gleaned from a Manila Times editorial that criticized the decision of the rickshaw company to import one-seater vehicles, when it could have

86. David Doherty, "Conditions in the Philippines", Paper presented to the Committee on the Philippines, US Senate, Fifty-Eighth Congress, Second Session, 27 February 1904, p. 6.

87. Gleeck, The American Half-Century, pp. 73-74.

88. “Doesn't Want Rickshas”, Manila Times, 22 January i902, p. 4. 
imported two-seaters from the Straits Settlements. ${ }^{89}$ Interestingly, Foreman shared his observation that there were also other Westerners in Manila who were unfamiliar with the rickshaw, an observation borne out of his expansive knowledge of other urban societies in Asia:

Other whites, unaccustomed to these vehicles, took to beating the runners - a thing never seen or heard of in Japan or in colonies where they are used in thousands. The natural result was that the 'rikisha man bolted and the 'rikisha tilted backwards, to the discomfort of the fool riding in it. ${ }^{9 \circ}$

Nonetheless, many Americans first encountered rickshaws through their experiences in Asian cities, mostly cosmopolitan treaty ports that hosted sizeable Western communities. ${ }^{91}$ For example, the members of the Philippine Commission rode rickshaws in Japan while they were on their way to the Philippines in May 1900. In contrast to West and Hart, the commissioners were quite happy with the rickshaws and the Japanese pullers, who were apparently accustomed to tourists. According to Bernard Moses, the Japanese coolies "had their own notion of what [the members of the Taft Commission] should see, derived doubtless from a composite of the demands of by-gone tourists". ${ }^{2}$ It is thus not far-fetched to assert that when William Howard Taft stated that he wanted to implement a rickshaw system in Manila, he was basing it on his experience in Japan. ${ }^{93}$

A transnational frame would have allowed tourists to appreciate comparative descriptions such as this one made by a I930s Manila travel guide: "The carretela and the carromata are to the Philippines, what the ricksha is to Japan and China." ${ }^{44}$ But such comparisons meant more than just a juxtaposition of vehicles found in different cities; a transnational frame also provided the space for racialist analyses. As will be elaborated in the succeeding section, the "natural dignity" of the Filipino, displayed in his resistance to rickshaw-pulling, was implicitly compared to the lack thereof among other Asian societies who had adopted rickshaws as a popular transport mode.

\section{OF FOREIGN VEHICLES AND ENSLAVED FILIPINOS}

Filipinos, particularly the educated classes, also had their perception of rickshaws shaped by a comparative, transnational frame, given their high

89. "The Rickshas", p. 4.

90. Foreman, The Philippine Islands, p. 635.

91. US Bureau of Insular Affairs, Monthly Summary of Commerce, p. I3; Cretcher, A Tenderfoot in the Tropics, p. I8.

92. Daniel Williams, The Odyssey of the Philippine Commission (Chicago, IL, I913).

93. Ibid., p. 24; Helen Taft, Recollections of Full Years (New York, 1914), pp. 57-58.

94. American Express Company, Manila and the Philippines (Manila, c.1933), p. 98. The carretela is a two-wheeled, animal-drawn freight vehicle. 
level of cosmopolitanism. Rizal lamented the fact that in Tokyo humans pulled rickshaws as if they were horses. ${ }^{95}$ The ilustrado Trinidad Pardo de Tavera was another example, but with a different angle from that of Rizal. In his article published in the Philippine Review, he narrated his experiences in early twentieth-century Hong Kong where a Filipino colony had the reputation of being "ungovernable, aggressive, undisciplined, and disorderly", ${ }^{6}$ due to their disrespect for the Chinese. So disorderly was their behavior that the police often had to intervene to control them. Pardo de Tavera recounted an incident when, as he passed through a group of Filipino sailors while riding a rickshaw, one of these sailors suddenly jeered at the coolie pulling the ilustrado's rickshaw. The sailor called the coolie caballo [horse]. Pardo de Tavera requested the puller to stop the vehicle and asked why the sailors were insulting the coolie. One of them replied: "Just because I want to." Pardo de Tavera scolded them and told them to respect the puller since he was "doing work as honorable as yours". According to the account, one of the sailors recognized Pardo de Tavera and told his companions who this person was. Pardo de Tavera said that afterwards, "[t]hey all thanked me for my intervention".

Similar to Pardo de Tavera's account was Ignacio Villamor's report prepared for the Board of Regents of the University of the Philippines in 1916 regarding the state of education in Japan. In that report Villamor expressed his appreciation for the values and industriousness of the Japanese. As an example, he juxtaposed the sense of camaraderie, discipline, and diligence of the Japanese rickshaw-pullers to the recklessness and "impetuousness" of Filipino cocheros and chauffeurs, attitudes which, according to Villamor, could not be observed in Japan. ${ }^{97}$

Pardo de Tavera and Villamor deployed the imagery of the rickshaw coolie in terms of hard work, humility, and perseverance vis-à-vis the negative traits of Filipinos. Such a comparison was patently similar to how most Americans viewed the rickshaw controversy. However, from the point of view of those opposed to the rickshaw system, the rickshaw symbolized an entirely different imagery. Still framed in a transnational and comparative manner, anti-rickshaw ideologues saw the rickshaw not only as a metaphor of slavery but also as a symbol of foreignness, and opposition to it stood for independence - freedom from a foreign entity and from enslavement.

Many Filipinos viewed the rickshaw as an entirely foreign vehicle. Indeed, the rickshaw was foreign, in the barest sense of the term. No rickshaws

95. Rizal, Letter to Ferdinand Blumentritt, p. 240.

96. Trinidad Pardo de Tavera, "Recollections of Hongkong, Kowloon, Macao and Canton", The Philippine Review, 5 (November 1920), p. 770.

97. Ignacio Villamor, “Japan's Educational Development”, in Fifth Annual Report of the President of the University of the Philippines: Manila, December I5, I9I6 (Manila, 1916), pp. 80-81. 
were manufactured in the country; all units were imported from Japan. Filipinos probably first heard of the existence of rickshaws from stories about Japan. ${ }^{98}$ What is more, at a figurative level, it appeared to many that rickshaws contained a foreign essence, totally alien to Filipinos. In its "Los Filipinos no son Brutos" statement, the UOD claimed that rickshaws should not be used in the Philippines because of the harm they could cause to pullers, given the incompatibility of rickshaw-pulling with the local climate. Comparing the climate of the Philippines with that of Asian countries where rickshaws were common, the statement asserted that in those places the climate was much milder, and yet statistics showed that during the first year of service one-quarter of the pullers died due to sunstroke, fevers, tuberculosis, and other diseases that they contracted due to profuse sweating. ${ }^{99}$ Supposedly, the unnaturalness of the rickshaw to the Philippine context could take a much greater toll on the health of potential Filipino pullers. Such an appreciation of the rickshaw as something totally foreign could also be observed in anecdotes even after the 1902 rickshaw controversy.

Though a public system of rickshaws was never attempted again in the wake of the 1902 controversy, on a few occasions rickshaws made their presence felt to Filipinos in different ways, but always understood as completely novel and bordering on the exotic. For example, Filipinos were shocked when on the morning of 28 July i 910 they saw a rickshaw plying the streets of Manila. This event was reported by the Manila Times and the tone of the article suggested that Filipinos were amazed by the "strange" vehicle imported from Japan. ${ }^{100}$ Stories about Filipinos facing the "alien" rickshaw were not limited to physical encounters.

Published years after 1902, a manual distributed by the Bureau of Education for English teachers in the country contained an interesting sample dialogue presented as an exercise for students. The fictional dialogue featured a Miss Villanueva talking to a Mr Campos, both presumably Filipinos, about her recent trip to Japan. Her story revolved around the experience that she and her mother had with a rickshaw and the accident they met with when the Japanese puller stumbled, fell, and broke his leg as a result. Although she flew into a ditch, Miss Villanueva recounted that she was not hurt. Rather symbolically, "a party of tourists came by in automobiles and took us [the two ladies] back to town". This hypothetical situation curiously juxtaposed the Villanuevas' unfamiliarity with their Japanese pullers - as both mother and daughter could not even "speak a word of Japanese" - and the ladies' "sense of security/comfort"

98. James Blount, The American Occupation of the Philippines, I898-19I2 (New York, I9I3), p. I9I.

99. "Los Filipinos no son brutos", El Comercio, ig May i902, p. 3.

ı००. "Ricksha gives Filipinos Shock", Manila Times, 28 July ı9ıо, p. I. 
after automobile-riding foreigners, presumably Westerners, "rescued" them from their predicament in a foreign land. ${ }^{\mathrm{IO}}$

While educated Filipinos like Pardo de Tavera and Villamor used their transnational mobility as a way of contrasting Filipinos' supposed lack of respect for the dignity of labor to the hardworking attitude of pullers in foreign lands, a number of cosmopolitan Filipinos did the opposite. Enrique Altavas, in narrating his voyage to Japan, related that the rickshaw is one of the first things that attract the attention of the visitor. He also gave his opinion regarding the rickshaw: "La primera vez que ocupé uno de estos rickshaws tuva [sic] una impresión desagradable, pues no podía avenirme fácilmente a la idea de 'animalizar', (si cabe la palabra), a un ser humano hecho a imagen y semejanza del Creador." ${ }^{\prime 02}$ Altavas left his reader with an image of the rickshaw as foreign (Japanese) and inherently degrading.

That a number of educated Filipinos viewed the rickshaw as essentially foreign and enslaving is not a trivial matter. The result of such an overlapping of meanings is the increased potency of the rickshaw as a symbol of oppression; but oppression not just of a puller-laborer by the rickshaw owner, but also of a colonized nation by a foreign ruler. To see the potency of the rickshaw as a symbol of colonial exploitation one has to go back to events before the 1902 rickshaw controversy. During the early years of American colonialism, an editorial cartoon of a Filipino pulling a carriage, à la rickshaw, with an American passenger circulated among the natives and became popular. ${ }^{103}$ At the same time, anecdotal evidence, which Taft himself presented before the US Senate, reported Filipino cocheros as expressing their concerns about the new regime in the following way:

When the American government is established here and the Americanos are in control $[\ldots]$ what kind of cart, wagon, or carromata shall I have to help pull, because I understand the Americans are buying up all the horses in the Philippines with a view to killing them, so that the Filipinos shall be made the beasts of burden. ${ }^{104}$

From educated ilustrados to ordinary carriage drivers, it appeared that the subjugation of the Philippines to another colonial power was as

ıо . Mary Helen Fee, Constructive Lessons in English Designed for Use in Intermediate Grades (Manila, I9I I), p. 70.

102. Enrique Altavas, Impresiones de viaje (Manila, 1920), p. 270: "The first time that I rode one of these rickshaws I had an unpleasant impression, as I could not easily reconcile myself with the idea of 'turning into an animal' (if such a phrase fits) a human being made in the image and likeness of the Creator."

103. Blount, The American Occupation of the Philippines, p. I91.

104. US Senate, Affairs in the Philippine Islands: Hearings before the Committee on the Philippines of the United States Senate (Washington DC, 1902), pp. 269-270. See also Pante, "The Cocheros of American-Occupied Manila", p. 455. 
degrading as the act of pulling a rickshaw. The intense opposition to Rivers's business was thus not surprising, given these circumstances. One must be reminded that the controversy erupted at a time when the American colonial state had just reached its fourth year and nationalist feeling was still high. Though Manila was quite far away from revolutionary battles and the war against the Americans was already nearing its end, nationalist fervor was still strong among Manila-based oppositionist groups, including the UOD. The wave of militancy that swept Manila during the first months of 1902, articulated by the likes of de los Reyes, was also propagated by antiUS sentiment. ${ }^{105}$ From the Filipino perspective, the anti-rickshaw campaign was not just a fight to preserve the Filipino workers' dignity, it also contained remnants of an iconography from very recent anti-colonial resistance.

The persistence of the iconography of the rickshaw from one context to another would be repeated years after the 1902 controversy, this time in an entirely different debate: the debate regarding the independence of the Philippines. In the campaign of Filipino nationalists for political independence, echoes of the controversy could still be heard in rhetoric deployed by Filipino politicians. Though the fight for independence through diplomatic means was something that had been an evident concern from the beginning of the colonial period, it only gained significant momentum with the passage of the I9I6 Philippine Act or the Jones Law. In Michael Salman's analysis of the campaign for independence, he noted that Filipino nationalists "wielded definitions of slavery as weapons" ${ }^{\text {I06 }}$ to push for their cause. The rickshawas-symbol became one such weapon.

In fighting for independence from the US, Filipino politician Isauro Gabaldon stated that a Filipino should be respected for the following reasons:

I respect the Filipino because he respects himself. There is an innate manliness about him. He has a deep-seated personal pride. No one could ever make a Filipino pull a rickshaw [...]. The present nationalistic movement of this country is an outgrowth of this Filipino trait. Because he respects himself he wishes to govern himself. ${ }^{107}$

Gabaldon's use of the rickshaw as a negative example to illustrate the political maturity of the Filipinos was echoed in the testimony before the US House Committee on Insular Affairs given by James Williams, the editor of various US-based publications who had spent four months in the Philippines. Yet in an ironic twist, Williams's deployment of the metaphorics of slavery was done to praise American colonial rule and

105. Mojares, Brains of the Nation, p. 279.

106. Salman, The Embarrassment of Slavery, pp. 3-4.

107. Isauro Gabaldon, "Why I Respect the Filipino", in US Senate, Seventy-First Congress, Independence for the Philippine Islands: Hearings before Committee on Territories and Insular Affairs (Washington DC, 1930), p. 339. 
support its continuation. His testimony was made to convince the US Congress that conditions in the Philippines under Governor-General Leonard Wood were most satisfactory. In his argument, he stated:

It is a very heartening condition to go through the Orient and finally arrive in Manila and the Philippines and find there that under American sovereignty there are no beggars, and there are no rickshas, in the Philippines. You travel in the Philippines by automobile or by carriage or other vehicle, but a fellow human being does not drag your vehicle through the streets, as he does in some other countries in the Orient. ${ }^{108}$

Apparently, it did not occur to Williams that it was Manila Americans who had pushed for the implementation of a rickshaw system in 1902.

Meanwhile, in an article that extolled the benefits of American colonial rule in the country, Kansas Governor Henry Allen related that when he visited the Philippines in 1927 Filipino leaders preferred the retention of colonial rule over independence that would supposedly leave the country vulnerable to other powers in Asia, including Japan. He then added:

Even the realization of this danger comes down to the people themselves. I asked the chauffeur who drove me about in Manila what he thought would happen if the United States gave the Philippines their freedom and disavowed further responsibility. He said that he was afraid that in a short time it would mean that he would be "pulling a rickshaw with a Japanese inside, rather than driving an automobile". ${ }^{\circ 9}$

Here was an American using the iconography of the rickshaw as both foreign and enslaving in an unprecedented manner: to depict the horrors of possible Japanese colonial rule in the Philippines.

\section{CONCLUSION}

In a recent article, David Arnold and Erich DeWald pointed out:

An argument for the social construction of these technologies in a colonial or semi-colonial context must, therefore, take a different form - in terms of how certain technological goods or practices were locally ignored or rejected, were subjected to significant local emendation and reinvention (like the various forms of the Asian cycle-rickshaw, itself a demonstration of substantial intraregional diversity), were reworked and reappropriated to conform with local cultural norms and social usages. ${ }^{\text {IO }}$

108. US House of Representatives, Hearing before the Committee on Insular Affairs, House of Representatives, Sixty-Ninth Congress, Second Session on H.R. I6868: A Bill to Clarify and Amend Existing Laws Relating to the Powers and Duties of the Auditor for the Philippine Islands and for Other Purposes, February 3, 4, 5, 7, and 8, 1927 (Washington DC, 1927), p. I Io. ı09. Henry Allen, "From Jagor to Major General Wood", The American Chamber of Commerce Journal, 7 (April 1927), p. 7.

I Iо. Arnold and DeWald, "Everyday Technology in South and Southeast Asia”, p. 6. 
This article is in part an answer to the call made by Arnold and DeWald. Although the Asian cycle-rickshaw that they mention is totally different from the rickshaws that were introduced in Manila in 1902, their ideas remain significant to this article. Indeed, the evolution of the old rickshaw into the modern Asian cycle-rickshaw show us how transport technology can exist in different reincarnations and reinventions in the polycentric world of Asia from colonial times to the contemporary world, a clear demonstration that innovations are not easily transplanted but are always contested by their recipients. ${ }^{\text {II }}$ But as the case of Manila demonstrates, even societies that shunned a certain piece of technology can also perform the processes of reworking and reappropriating.

Innovation is not always perceived as positive, for, as shown in the case of rickshaws in Manila, a new form of transportation was rejected. But behind this controversial act of rejection was the creation and deployment of new meanings to otherwise "neutral" objects. As shown in this article, the rickshaw was presented by its opponents as essentially foreign and oppressive, a mechanism to turn pullers into slaves. Significantly, such a depiction of the rickshaw in Manila came decades before the British had foregrounded the same imagery in its campaign to eradicate rickshaws in Singapore in the late I920s. ${ }^{\text {II }}$ Manila has illustrated that although the technological diffusion of the rickshaw into the city was very minimal and even rejected outright by key social groups, the meanings ascribed to both the technological artifact and the labor attached to the new technology were highly enriched by transnational movements of people and their ideas.

However, such meanings have been created and deployed mainly by the middle class, such as the articulate leaders of the UOD. One is thus left wondering about the perceptions of both rickshaw-pullers and cocheros. How did they view their occupation and the notion of dignity of labor? This question is impossible to answer given that these workers have left us with no letters or memoirs as sources of historical information. ${ }^{\mathrm{II}} 3$

Nonetheless, their actions, as reported by mainstream media and other upper- and middle-class eyewitnesses, allow us to gain more insights about workers, not as individuals, but as active social groups. One such insight is the significance of national ties in securing economic and political interests in a particular locality. While both Chinese coolies and Filipino cocheros were subordinate classes whose labor was exploited for the accumulation of wealth, the latter gained a better political position as

I I I. For similar considerations on colonial Africa see Jan-Bart Gewald, André Leliveld, and Iva Peša, "Introduction: Transforming Innovations in Africa: Explorative Studies on Appropriation in African Societies", in idem (eds), Transforming Innovations in Africa: Explorative Studies on Appropriation in African Societies (Leiden, 201 2), pp. I-I $5,7$.

I I 2. Warren, Rickshaw Coolie, p. Ioo.

I 13. Pante, "The Cocheros of American-Occupied Manila", p. 456. 
they allied themselves with the nationalist labor federation. Unfortunately, the nationalist orientation of the UOD prevented it from establishing ties with the migrant coolies despite apparent class solidarities. And there is an ironic twist: although transnational flows helped shape the UOD's opposition to the rickshaw, it was a strong nationalist agenda that became the primary weapon that led to the demise of the business. As such, while global connectivity transformed Manila by giving it new forms of technology (the rickshaw), labor (Chinese coolies), and capital (American investment), the local context, as defined by a smoldering anti-colonial nationalism, remained crucial in influencing the outcome of historical events. 